\title{
HUBUNGAN TINGKAT PENGETAHUAN TENTANG MENOPAUSE DENGAN KECEMASAN MENGHADAPI MENOPAUSE PADA IBU PEMBINAAN KESEJAHTERAAN KELUARGA
}

\author{
Relationships of Knowledge Level About Menopause With Anxiety Facing the Menopause in \\ Mother Family Well-Being Development
}

\begin{abstract}
Ni Putu Sri Widyantari ${ }^{1}$, I Putu Artha Wijaya ${ }^{2}$, I Made Dwie Pradnya Susila ${ }^{3}$
${ }^{1}$ Mahasiswa Program Studi S1 Keperawatan, STIKES Bina Usada Bali, Badung, Bali, Indonesia

${ }^{2}$ Departemen Keperawatan Medikal Bedah, STIKES Bina Usada Bali, Badung, Bali, Indonesia

${ }^{3}$ Departemen Keperawatan Gawat Darurat, STIKES Bina Usada Bali, Badung, Bali, Indonesia Korespondensi : sriwidyantari0197@gmail.com
\end{abstract}

\begin{abstract}
ABSTRAK
Menopause merupakan siklus berhentinya menstruasi yang akan dialami oleh semua wanita dengan tanda gejala dan keluhan yang berbeda. Jika tidak ditangani dengan baik akan menimbulkan dampak buruk bagi kesehatan, salah satunya kecemasan. Tujuan penelitian ini adalah untuk mengetahui hubungan tingkat pengetahuan tentang menopause dengan kecemasan menghadapi menopause pada ibuibu pembinaan kesejahteraan keluarga di Banjar Kaja Desa Buduk Kecamatan Mengwi Kabupaten Badung. Jenis penelitian ini adalah kuantitatif dengan desaign cross sectional. Sampel dalam penelitian ini adalah sebanyak 73 responden wanita yang berusia 45-55 tahun. Teknik pengambilan sampel dengan purposive sampling. Pengumpulan data menggunakan kuisoner tingkat pengetahuan dan kuisoner tingkat kecemasan. Analisa data mengguanakan uji spearman rank dengan nilai $\alpha<0,05$. Hasil analisa statistik menunjukkan nilai $p$-value $=0.0001$, maka dapat disimpulkan bahwa ada hubungan yang signifikan antara tingkat pengetahuan tentang menopause dengan kecemasan menghadapi menopause pada ibu-ibu pembinaan kesejahteraan keluarga di Banjar Kaja Desa Buduk Kecamatan Mengwi Kabupaten Badung.
\end{abstract}

Kata kunci : pengetahuan, menopause, kecemasan

\begin{abstract}
Menopause is the cessation of menstruation cycle that will be experienced by all women with different signs and symptoms. If not handled properly will cause adverse effects on health, one of them is anxiety. The purpose of this study was to determine the relationship of the level of knowledge about menopause with anxiety facing the menopause in mother family well-being development on Banjar Kaja Buduk Village, Mengwi District Badung Regency. This type of research is quantitative with cross sectional design. The sample in this study were 73 female respondents aged 45-55 years. The sampling technique was purposive sampling. Data collection uses knowledge level questionnaire and anxiety level questionnaire. Data analysis uses the Spearman rank test with a value of $\alpha<0.05$. The results of statistical analysis show the $p$-value $=$ 0.0001 , it can be concluded that there is a significant relationship between the level of knowledge about menopause with anxiety facing menopause in mothers fostering family welfare in Banjar Kaja Buduk Village, Mengwi District, Badung Regency.
\end{abstract}

Keywords : knowledge, menopause, anxiety 


\section{PENDAHULUAN}

Menopause merupakan henti haid terakhir yang terjadi dalam masa menopause yang disertai dengan tidak terbentuknya hormon estrogen. Masa menopause pada umumnya terjadi pada wanita yang berusia 45-55 tahun. Ssekitar 70-80\% wanita Eropa, 60\% di Amerika, $57 \%$ di Malaysia, $18 \%$ di Cina, dan $10 \%$ di Jepang, dan $10 \%$ di Indonesia mengalami perubahan dari fase premenopause ke fase menopause (Proverawati \& Sulistyawati, 2010). Berdasarkan Badan Pusat Statistik, pada tahun 2015 jumlah wanita di Indonesia yang memasuki menopause mencapai 21,22 juta jiwa. Diperkirakan pada tahun 2025 akan ada 60 juta wanita menopause. Jumlah prevalensi wanita di Bali pada tahun 2015 sebanyak 2.108.077 jiwa orang. Prevalensi jumlah wanita di Kabupaten Badung sebanyak 302.144 juta jiwa orang, diikuti oleh Kabupaten Gianyar sebanyak 245.219 juta jiwa orang, Kabupaten Jembrana 136.862 juta jiwa orang, dan di Kabupaten Klungkung sebanyak 88.804 juta jiwa orang (Badan Pusat Statistik, 2015).

Pada fase menopause akan mengalami perubahan berupa penurunan produksi hormon seks yaitu estrogen dan progesteron. Keluhan pada menopause berupa insomnia, hot flash, keluar keringat di malam hari, pusing, sakit kepala terus menerus, rasa nyeri di persendian, rasa tertekan tanpa sebab, rasa sakit saat berhubungan intim, vagina yang kering dan masih banyak lagi. Selain gejala - gejala fisik wanita menopause juga akan mengalami gejala psikologis. Semua perubahan tersebut akan dialami oleh semua wanita, sebelum terjadi fase menopause biasanya didahului dengan fase pramenopause (Proverawati \& Sulistyawati, 2010).
Salah satu gejala dari menopause yaitu gangguan psikologi berupa cemas. Kecemasan yang mereka alami sering kali dihubungkan dengan perasaan kekhawatiran yang belum pernah terjadi sebelumnya. Kecemasan pada setiap individu berbeda-beda, ada yang ringan, sedang dan ada juga yang berat, sehingga membutuhkan upaya penanganan untuk mengatasi masalah kecemasan yang dialami (Lestary, 2010). Umumnya wanita kurang mendapatkan informasi yang benar sehingga difikirannya yang ada hanya efek negatif yang akan dialami setelah terjadi masa menopause (Rostiana \& Kurniati, 2009). Kurangnya informasi yang didapat akan mempengaruhi tingkat pengetahuan seseorang, jika seseorang didasari oleh pengetahuan maka akan lebih bermanfaat daripada seseorang yang tidak didasari oleh pengetahuan (Damayanti, 2012).

Studi pendahuluan yang peneliti lakukan di Banjar Kaja Desa Buduk Kecamatan Mengwi Kabupaten Badung, diperoleh data 7 dari $10 \mathrm{ibu}-$ ibu PKK tidak mengetahui gejala dan dampak dari menopause sehingga menimbulkan gejala psikologi berupa kecemasan. Untuk itu, dibutuhkan penelitian lebih lanjut tentang hubungan tingkat pengetahuan pada ibu Pembinaan Kesejahteraan Keluarga (PKK) tentang menopause dan kecemasan untuk menghadapi fase tersebut.

\section{TUJUAN PENELITIAN}

Penelitian ini bertujuan untuk mengetahui hubungan tingkat pengetahuan tentang menopause dengan kecemasan menghadapi menopause pada ibu-ibu PKK. 


\section{METODE PENELITIAN}

Desain

Penelitian ini menggunakan desain penelitian korelasional dan dengan rancangan penelitian cross sectional yaitu merupakan jenis penelitian yang menekankan waktu pengukuran observasional data variabel independen dan dependen hanya satu kali pada satu waktu.

\section{Populasi dan Sampel}

Populasi dalam penelitian ini adalah ibu-ibu PKK di Banjar Kaja Desa Buduk sebanyak 90 orang. Jumlah sampel dalam penelitian ini sebanyak 73 responden. Pengambilan sampel dalam penelitian ini menggunakan teknik nonprobability sampling jenis purposive sampling. Dalam penelitian ini sampel yang diambil harus memenuhi kriteria ibu yang berusia 45-55 tahun; ibu yang masih produktif; ibu anggota PKK di Banjar Kaja; ibu yang dirawat di rumah sakit; ibu yang bedrest; ibu yang mengalami gangguan pendengaran dan penglihatan.

\section{Tempat dan Waktu Penelitian}

Penelitian ini dilakukan sejak Bulan Agustus 2018 sampai dengan Februari 2019. Lokasi penelitian di Banjar Kaja Desa Buduk Kecamatan Mengwi Kabupaten Badung.

\section{Instrumen dan Prosedur Pengukuran}

Instrumen yang digunakan dalam pengumpulan data adalah kuisoner tingkat pengetahuan dan kuisoner tingkat kecemasan. Kuisioner diberikan kepada responden, responden yang mengalami kesulitan dalam pengisian akan dibantu oleh peneliti.

\section{Analisa Data}

Analisa data mengguanakan uji spearman rank dengan nilai $\alpha=0,05$.

\section{HASIL PENELITIAN}

Hasil yang disajikan dalam penelitian ini yaitu sebagai berikut:

Tabel 1.

Hubungan Tingkat Pengetahuan

Tentang Menopause Dengan

Kecemasan Menghadapi Menopause Pada Ibu PKK ( $\mathrm{n}=73)$

\begin{tabular}{lccl}
\hline \multicolumn{1}{c}{ Variabel } & F & $\%$ & p-value \\
\cline { 1 - 2 } Pengetahuan & \multicolumn{1}{c}{0} & \\
Baik & 13 & 18 & \\
Cukup & 22 & 30 & \\
Kurang & 38 & 52 & \\
\cline { 1 - 2 } Tingkat Kecemasan & \multicolumn{1}{c}{0.0001} \\
Tidak ada gejala & 1 & 1 & \\
Gejala ringan & 10 & 14 & \\
Gejala sedang & 20 & 27 & \\
Gejala berat & 34 & 47 & \\
Panik & 8 & 11 & \\
\hline
\end{tabular}

Pada tabel 1 menunjukkan bahwa tingkat pengetahuan ibu tentang menopause sebagian besar berada pada tingkat pengetahuan kurang terbanyak yaitu 38 responden (52\%). Untuk tingkat kecemasan ibu menghadapi menopause didominasi oleh responden yang merasakan kecemasan dengan gejala berat yaitu sejumlah 34 responden (47\%). Hasil uji hipotesis menggunakan spearman rank menunjukkan nilai $\mathrm{p}$ sebesar 0,0001 dengan nilai $\alpha<0,05$ yang menunjukkan terdapat hubungan antara tingkat pengetahuan tentang menopause dengan tingkat kecemasan menghadapi menopause pada ibu-ibu PKK.

\section{PEMBAHASAN}

Hasil penelitian ini menunjukkan sebagian besar memiliki pengetahuan yang kurang terhadap menopause. Tingkat kecemasan ibu PKK dalam menghadapi menopause sebagian besar merasakan gejala kecemasan berat. Hasil uji hipotesis diperoleh nilai statistik yang bermakna terdapat hubungan antara tingkat pengetahuan dengan kecemasan ibu menghadapi menopause. Ibu-ibu yang mengalami menopause lebih dominan mengalami kecemasan. Kecemasan timbul sebagai akibat dari kekhawatiran yang 
menghantui dalam menghadapi situasi yang sebelumya belum dikhawatirkan (Pieter \& Lubis, 2010). Berdasarkan konsep ilmu psikologis yang menggunakan pendekatan kognitif, gangguan emosi dalam hal ini kecemasaan yang dialami individu ditentukan oleh penilaian individu terhadap peristiwa yang dialami. Selain itu seseorang yang mengalami menopause kurang mendapatkan informasi yang objektif tentang menopause khususnya bagi wanita yang belum mengalami menopause (Manuaba, 2010).

Pengetahuan merupakan hasil dari sebuah proses penginderaan terhadap obyek tertentu. Individu dapat dikatakan memiliki tingkat pengetahuan yang baik tentang menopause jika didukung oleh banyak sumber informasi yang diperoleh. Semakin banyak informasi yang diperoleh maka tingkat pengetahuan individu tersebut akan semakin baik (Ismiyati, 2010). Pengetahuan yang cukup akan membantu wanita memahami dalam mempersiapkan diri menghadapi masa menopause dengan lebih baik (Kasdu, 2002). Dengan kesiapan diri yang lebih baik maka ibu yang mengalami pra menopause dapat meminimalkan gejala kecemasan yang dialami.

\section{KESIMPULAN}

Implikasi

Seorang wanita menjelang masa menopause harus dapat menyesuaikan diri dengan kondisi yang dialami. Resiko kecemasan yang mungkin terjadi dapat ditekan jika individu siap dengan masa menopause. Hasil dalam penelitian ini menunjukkan faktor pengetahuan sangat berhubungan dengan kecemasan dalam menghadapi menopause. Informasi dan faktor pengalaman menjadi sangat penting dalam menambah pengetahuan kesehatan yang lebih baik.

\section{Keterbatasan}

Peneliti belum melakukan pengamatan secara menyeluruh tentang faktor yang mempengaruhi kecemasan menghadapi menopause. Determinan yang berbeda dapat diteliti dimasa mendatang untuk lebih meningkatkan wawasan tentang menopause dan penanganannya sehingga dapat mengurangi kecemasan ibu dan tidak tergantung pada tingkat pengetahuan saja.

\section{DAFTAR PUSTAKA}

Badan Pusat Statistik. (2015). Proyeksi Penduduk Provinsi Bali Menurut Jenis Kelamin dan Kabupaten/Kota, 2011-2020. Retrieved November 2, 2018, from https://bali.bps.go.id/ dynamictable/2017/03/25/115/proyek si-penduduk-provinsi-bali-menurutjenis-kelamin-dan-kabupaten-kota2011-2020-ribu-jiwa-.html

Damayanti, F. N. (2012). Hubungan Tingkat Pengetahuan dan Upaya Penanganan Ibu Dengan Kecemasan Dalam Menghadapi Menopause di Kelurahan Genuksari Kecamatan Genuk Kota Semarang. Dinamika Kebidanan, 2(1), 1-14.

Ismiyati, A. (2010). Hubungan Tingkat Pengetahuan Tentang Menopause Dengan Kesiapan Menghadapi Menopause Pada Ibu Premenopause di Perumahan Sewon Asri Yogyakarta. Universias Sebelas Maret.

Kasdu, D. (2002). Kiat Sehat dan Bahagian di Usia Menopasue. Jakarta: Puspa Swara.

Lestary, D. (2010). Seluk Beluk Menopause. Jakarta: Graha Ilmu.

Manuaba, I. B. G. (2010). Memahami Kesehatan Reproduksi Wanita (2nd ed.). Jakarta: EGC.

Pieter, H. Z., \& Lubis, N. L. (2010). Pengantar Psikologi untuk Kebidanan (Revisi). Jakarta: Kencana Media.

Proverawati, A., \& Sulistyawati, E. (2010). Menopause dan Sindrom Premenopause. Yogyakarta: Nuha Medika.

Rostiana, T., \& Kurniati, N. M. T. (2009). Kecemasan pada Wanita yang Menghadapi Menopause. Jurnal Psikologi, 3(1), 16-24. 